\title{
The effects of cash transfers on adult labor market outcomes
}

\author{
Sarah Baird ${ }^{1 *}$, David McKenzie ${ }^{2}$ and Berk Özler ${ }^{2}$
}

\author{
* Correspondence: sbaird@email. \\ gwu.edu \\ ${ }^{1}$ Department of Global Health at \\ the Milken Institute School of Public \\ Health, George Washington \\ University, Washington, DC, USA \\ Full list of author information is \\ available at the end of the article
}

\begin{abstract}
The basic economic model of labor supply has a very clear prediction of what we should expect when an adult receives an unexpected cash windfall: they should work less and earn less. This intuition underlies concerns that many types of cash transfers, ranging from government benefits to migrant remittances, will undermine work ethics and make recipients lazy. We discuss a range of additional channels to this simple labor-leisure trade-off that can make this intuition misleading in low- and middle-income countries, including missing markets, price effects from conditions attached to transfers, and dynamic and general equilibrium effects. We use this as a lens through which to examine the evidence on the adult labor market impacts of a wide range of cash transfer programs: government transfers, charitable giving and humanitarian transfers, remittances, cash assistance for job search, cash transfers for business start-up, and bundled interventions. Overall, cash transfers that are made without an explicit employment focus (such as conditional and unconditional cash transfers, and remittances) tend to result in little to no change in adult labor. The main exceptions are transfers to the elderly and to some refugees, who reduce work. In contrast, transfers made for job search assistance or business start-up tend to increase adult labor supply and earnings, with the likely main channels being the alleviation of liquidity and risk constraints.
\end{abstract}

JEL Classification: O15, J22, 138, H23

Keywords: Cash transfers, Labor supply, Remittances, CCTs

\section{Introduction}

Cash transfers are a key component of social protection globally, and there is a growing interest in the promise of cash transfers to improve outcomes for poor people in low-, middle-, and even high-income countries. The interest is evident not only among researchers, but also among governments and those in the humanitarian aid and charitable donation space, evidenced by the popularity of organizations like GiveDirectly and the report of a high-level panel on cash transfers and humanitarian aid (ODI 2015). The impacts of cash transfers on education, health, early childhood development, poverty, and inequality, as well as intra-household bargaining power and female empowerment has not only been the subject of many empirical studies in low- and middle-income countries (LMICs), but also of systematic reviews (see, e.g., Baird et al. 2014 and Manley et al. 2013 on the effects of cash transfers on education and nutrition, respectively).

(c) The Author(s). 2018 Open Access This article is distributed under the terms of the Creative Commons Attribution 4.0 International License (http://creativecommons.org/licenses/by/4.0/), which permits unrestricted use, distribution, and reproduction in any medium, provided you give appropriate credit to the original author(s) and the source, provide a link to the Creative Commons license, and indicate if changes were made. 
However, the effect of cash transfer programs on labor market-related outcomeswhether directly or in combination with other interventions-has not received as much attention. While there is a sizeable literature on the effect of cash transfers on the profits and growth of microenterprises (see, e.g., De Mel et al. 2008, 2012; McKenzie and Woodruff 2008; Fafchamps et al. 2014, among others), the effects of cash transfers on the ability of poor households to start small businesses, search for and find jobs in the formal or informal sector, or attend job training programs are much more limited. This paper attempts to synthesize the existing evidence on cash transfers and labor market outcomes and draw some conclusions on where we are, what may be promising, and what is yet to be tried and tested.

The potential scope of this review is vast, both in terms of the intervention space and the outcome space. We do not attempt to undertake a formal systematic review, but rather conduct what Evans and Popova (2016) call a narrative review. ${ }^{1}$ We present a structured overview of studies we view as well-identified quantitative studies, including both experimental and quasi-experimental designs. The studies reviewed here were chosen by each of the authors based on their expertise and familiarity with the literature in their sub-fields. In terms of interventions, we choose to focus on the following: government cash transfer programs, cash transfers by NGOs, private cash transfers in the form of remittances, cash transfers for search assistance and finding work, cash transfers for small business start-up and growth, and cash transfers to the ultra-poor. We exclude cash transfers in the workfare space as these are directly providing work and more comparable to training programs-we are focused on cash that is not specifically conditional on some kind of work. We also exclude tax credits like the Earned Income Tax Credit, as these are not particularly prevalent in LMIC contexts. In terms of outcomes, we focus on adults and include employment, hours worked, income (wage and profits), and type of work.

The rest of the paper is organized as follows. Section 2 discusses the theoretical foundations for the impact of cash transfers on labor supply and labor earnings. Section 3 summarizes the evidence and Section 4 concludes.

\section{What does theory predict should happen to labor supply and labor earnings when individuals receive cash transfers?}

The standard ("Econ 101") economic model of labor supply has a very clear prediction of what we should expect when an individual suddenly receives an unexpected cash windfall: individuals should work less and earn less. In these models, individuals decide how much to work by trading off the gain from working more hours (more income) against the cost (less leisure). Since leisure is usually regarded as a normal good, an increase in non-work income should then cause an individual to demand more leisure (e.g., Becker 1965), and therefore work less. Indeed, Keynes (1930) infamously predicted that because people would be so much richer in the future, his grandchildren would only work $15 \mathrm{~h}$ per week. Recent studies of lottery winners in Sweden (Cesarini et al. 2017) and the Netherlands (Picchio M, Suetens S, van Ours J: Labour supply effects of winning a lottery, forthcoming) are in line with this prediction, with winning a prize reducing the number of hours worked and the amount of income earned.

So why might this simple framework not be enough to explain labor responses to cash transfers in low- and middle-income countries? We can think of a number of 
possible channels, which can be broadly grouped as arising from missing markets, price effects from behavioral conditions attached to transfers, and dynamic and general equilibrium effects.

\subsection{Missing markets}

The standard model becomes more complicated when we introduce liquidity constraints that prevent people from undertaking certain investments that would enable them to earn a lot more, and when incomplete insurance coupled with risk makes them hesitant to undertake some of these investments. Cash transfers can help individuals overcome these constraints and therefore change labor supply and labor earnings through a channel other than the income effect.

One channel is through a health productivity effect. Poor, undernourished workers who cannot borrow may not be very productive at work (e.g., Dasgupta and Ray 1986). A cash transfer may allow these individuals to buy more food and better nutrients, which can allow them to earn more from each hour of work. This could increase labor earnings, and because the effective wage rate has increased, the substitution effect may also lead to individuals working more hours. ${ }^{2}$

A second channel is through a self-employment liquidity effect. Individuals with good ideas for starting businesses, but no access to credit, may have not been able to run a business, or may be running smaller businesses than they would like. A cash transfer, by alleviating the credit constraint, allows them to expand these businesses and earn more income. Labor hours could increase if the return to an additional hour of labor has changed, or decrease if they can buy capital equipment to substitute for their previous labor.

A third channel is an insurance effect: poor individuals may not attempt to undertake risky activities with high potential rewards (like starting a business or migrating to a better job) because of the risk of failure. Access to a steady stream of cash transfers can provide insurance against this possibility, leading to higher expected labor earnings and more hours in self-employment.

Finally, there is the investment in labor search effect. The Econ 101 model does not have involuntary unemployment. But in practice search frictions mean that workers have to search to find matches with employers, and may be unemployed while looking for a good match. Poor individuals with liquidity constraints will not be able to afford to search for long, and so will either take a low wage job, or stop searching. They may also eschew searching for jobs for which the returns are high but risky. A cash transfer may fund longer and more intensive search efforts. This may reduce employment in the short run, as workers take longer to find a good match, but increase employment and wages in the long run.

\subsection{Price effects from behavioral conditions attached to transfers}

All of the above channels could operate even if cash transfers were suddenly given to individuals with no conditions attached. But in practice many cash transfers are only given to individuals and households that satisfy certain eligibility criteria and/or that undertake specified actions. These conditions can effectively change the relative prices of labor and leisure, which can in turn affect labor supply and labor earnings.

Some cash transfers may be conditioned explicitly on work (or lack thereof). Cash will only be given if the recipients agree to start a business, which will increase the return 
to working. In contrast, there could be a deterrence effect that reduces labor if individuals are concerned that earning too much will disqualify them from eligibility for future transfers, or if migrating in search of better job opportunities will make the individual no longer eligible for transfers.

Other cash transfers may be conditioned on time-consuming activities. Many conditional cash transfers require that parents take children to regular health clinics and that children attend school. Both reduce the time available for children to work and are likely to decrease child labor. In contrast, they can have opposing impacts on the time available for parents to work-health visits and other such activities may take time away from work, while increased school attendance for children may make it easier for parents to work.

Adult labor outcomes of individuals whose households receive cash transfers when they are children can also be affected through a human capital accumulation liquidity and conditioning effect. Cash transfers lead to children getting more education, and this education in turn then can affect the likelihood of work, the type of work, and the income earned from work as adults.

\subsection{Dynamic and general equilibrium effects}

The standard model considers an individual making a one-period labor supply choice, which does not affect their future ability to work nor is it affected by decisions others are making. Neither assumption may hold. There may be a human capital depreciation/scarring effect where time out of the workforce can cause workers to lose skills and make it harder to find jobs in the future. If cash transfers are known to be only temporary, this effect will cause individuals not to reduce labor as much as the standard model would predict. There may also be general equilibrium effects. The fact that other community members also receive cash transfers can have additional impacts on an individual's own labor supply. These effects could increase the amount worked (e.g., if other members cut back on hours, wage will rise; spending by other community members may act as a demand shock for those running their own businesses) or decrease the amount worked (the value of leisure may increase if friends are also not working).

\subsection{Summary}

Taken together, these potential channels show that there are many reasons why the labor response to cash transfers need not be as simple as that predicted by an "Econ 101" model of the labor/leisure trade-off. Most of these channels provide mechanisms to offset the fall in labor expected with higher income, or to even result in an increase in labor hours and earnings. Nevertheless, there are also potential mechanisms that could make the reduction in labor earnings even larger than the pure income effect would predict. We therefore turn to the empirical evidence to see what has happened when individuals in LMICs receive cash transfers.

\section{What happens in practice with different types of programs?}

\subsection{Government cash transfers}

Government cash transfer programs-both conditional and unconditional-are the most ubiquitous (and most evaluated) social protection policies globally-with 52 countries with a conditional (CCT) and 119 countries with an unconditional (UCT) cash transfer 
program (Gentilini et al. 2014). Government CCTs are typically targeted at poor households with children and involve small, regular cash payments to the household conditional on a certain set of behaviors usually related to children's education or health. UCTs also typically target the poor, but are not conditioned on any specific behavior. Old-age pension programs and child support grants are the most common forms of UCTs, but some programs also target orphans and vulnerable children. As mentioned above, there is a wealth of evidence on the impact of government CCTs and UCTs on health and education, but a much more limited body of evidence on adult labor market outcomes.

CCTs and UCTs, targeted at poor families with children, can have effects on adult labor market outcomes for two distinct groups of target populations: the children, whose future participation and remuneration in the labor market is affected through increased human capital accumulation, and adults, who may change their labor market participation in response to the increased current income and within-household substitution effects (e.g., in response to decreasing child labor). ${ }^{3}$ Below, we describe the effects of cash transfer programs on labor market outcomes of adult beneficiaries in the shorter run (generally 2- to 5-year follow-ups), followed by effects on future outcomes of adolescents in the longer run (typically 5- to 10-year follow-ups).

The most well-known government CCT program is Mexico's PROGRESA, which later became Oportunidades. Parker and Todd (2017) provide a review of its effects on labor market outcomes for adult beneficiaries and find no effects on work or leisure (citing Parker and Skoufias 2000; Rubio-Codina 2010). They note some effect on women substituting for children's time within the household, because child labor (including paid, domestic, and household agricultural) goes down under PROGRESA/Oportunidades. Bianchi and Bobba (2013) find that expected future transfers increase the probability of entrepreneurship (self-employment) in the short run. However, this effect disappears in the medium run, remaining only in areas with low levels of self-employment at baseline, (canceled by a negative effect in areas with high self-employment at baseline). Finally, Gertler et al. (2012) observe a positive short-term impact on non-agricultural microenterprises and total agricultural income among treated households. However, in the medium term, i.e., 5-6 years after the start of the program, they find no effects on outside wages. In summary, the effect of Mexico's CCT program on the labor market outcomes of its adult beneficiaries is small at best.

Banerjee et al. (2017) re-analyze the results of seven randomized controlled trials of government-run CCT programs from six countries to examine impacts on labor supply. ${ }^{4}$ The authors do not observe a significant effect either individually or pooled on employment or hours of work. Similarly, they find no pooled effect on whether work is self-employed/ within family vs. outside the household. They do find a decrease in outside work and an associated increase in within household work in PROGRESA, but the opposite pattern holds for RPS (which has a similar transfer size). Similarly, there are no overall pooled effects on any outcomes when disaggregating by gender. ${ }^{5}$

Elsewhere, examining two similar unconditional cash transfer programs in Malawi and Zambia targeting labor-constrained households (i.e., households with high dependency ratios), (de Hoop J, Groppo V, Handa S: Household micro-entrepreneurial activity and child work: evidence from two African unconditional cash transfer programs, submitted) find that such households substitute away from working as wage laborers and start spending more time in own-agricultural work in both countries. In Zambia, overall economic activity 
increases, along with participation in non-agricultural household businesses, while these changes are not observed in Malawi. ${ }^{6}$ Evaluating the effects of a 2-year child grant program in Zambia (targeted to households with children under the age of three), Prifti et al. (2017) find similar switches from off-farm paid work to own-farm labor, along with increases in hired agricultural labor among beneficiary households. Using the same RCT, Handa et al. (2018) find increases in the likelihood of operating a non-farm enterprise and revenues from those enterprises for the Child Grant Program (CGP), but not the multiple category targeted program (MCP) for labor-constrained households. ${ }^{7}$

While Child Support Grants target families with children, old age pension programs target the elderly. These schemes affect not only the labor supply of the elderly beneficiaries themselves, but also of the prime-aged adults and children, who are related to pensioners or would-be pensioners. Below, we summarize the findings from South Africa's old age pension scheme (OAP), which is perhaps as well-known and well-studied as Mexico's PROGRESA.

Bertrand et al. (2003) find sharp decreases in the labor supply of prime-aged individuals living with elderly (household members, aged 16-50) around the time they become eligible for pensions, especially when the pensioner is female. ${ }^{8}$ The effects are both on employment status (extensive margin) and on hours worked (intensive margin), larger for older adults, and largest for the oldest son. Posel et al. (2006), however, find that when they focus on non-resident household members, they find that African females, but not males, are more likely to be migrant workers in female-pensioner households. Ardington et al. (2009) argue that the OAP increases employment among prime-aged adults, by easing credit constraints for migration and job search and by increasing the availability of elderly to care for small children. Ranchhod (2006) finds that pension eligibility causes large declines in labor force participation among the elderly themselves, as well as an increase in flextime work along with a reduction in hours worked among those who stay in the labor force. Lam et al. (2006) also find that age of pension eligibility is associated with accelerated rates of retirement, faster for men than women, but not as high as the jumps in retirement observed in European countries. ${ }^{9}$ They also point out that many elderly persons live in three- or skipped-generation households, which may in part be a response to the OAP itself (Hamoudi and Thomas 2014) and makes interpretation of studies that treat the OAP as exogenous more difficult. The causal identification of the effects of pension eligibility is therefore likely to be more credible for the labor market responses of the elderly themselves (Lam et al. 2006; Ranchhod 2006) than the working age adult relatives living in their households (Bertrand et al. 2003; Ardington et al. 2009).

We conclude this section by discussing the labor market outcomes of young adults, who were exposed to a CCT or a UCT program as children in beneficiary households. Behrman et al. (2011) observe weak positive effects on working (labor force participation) for females who were 13-15 just prior to the start of PROGRESA 6 years later. For males 13-15 at baseline, they find a weak negative effect on working in agriculture-possibly since some are still in school. ${ }^{10}$ Several recent evaluations of cash transfer programs from Asia, Latin America, and Africa have added to the evidence base on the effects of cash transfers on the future outcomes of child beneficiaries. In Cambodia, Filmer and Schady (2014) examine the effects of a 3-year secondary school scholarship program and find no effects on employment or earnings 5 years after baseline (2 years after the end of transfers/ scholarship funds). ${ }^{11}$ In Ecuador, Araujo et al. (2016) find no effect of large cash transfers 
on employment 10 years after the start of the program among young adults aged 19-25. In Nicaragua, Barham et al. (2017) examine a CCT program, focusing their analysis on a sub-group most at-risk for dropout from school (boys, aged 9-12), so that program impacts on human capital accumulation are substantive. In this sub-group, 10 years after baseline, they find significant and meaningful increases in labor force participation (0.236 SD effect on a LFP index) and earnings (0.192 SD effect on an earnings index). Off-farm employment, migrating for work, salaried non-agricultural employment, and monthly earnings are all substantially higher for this group of young men. In Honduras, 2 years of receiving vouchers for health and education (conditional on mothers attending pre-natal check-ups and children attending school, among other requirements) caused no long-term effect on the labor market outcomes of young adults (Ham and Michelsen 2018). However, when combined with supply-side incentives tied to improvements in the quality of service delivery, there were small effects on young women's labor force participation, but not on men's.

In contrast to the findings in Nicaragua, but more in line with those in Cambodia and Ecuador, (Baird S, McIntosh C, Özler B: When the Money Runs Out: Do Cash Transfers Have Sustained Effects?, unpublished) evaluate the medium-term labor market effects of a 2-year cash transfer experiment targeted to initially never-married young women in Zomba, Malawi. ${ }^{12}$ Five years after baseline (and 2 years after the cessation of transfers), the authors find no impact of either the conditional or the unconditional cash transfer intervention on the likelihood of any wage work in the past 3 months, effective daily wage in the past week, hours spent in self-employment or paid work, or labor income in the past five seasons (15 months), nor were there any effects on assessments of basic labor market skills relevant for rural Malawi, such as reading and following instructions to apply fertilizer, making correct change during a hypothetical market transaction, sending a text message and using a calculator on a mobile phone, or calculating profits for a hypothetical business scenario.

\subsection{Charitable giving and humanitarian cash transfers}

GiveDirectly is a non-profit charity organization that provides cash transfers to poor households via mobile phone in Kenya, Uganda, and Rwanda. Haushofer and Shapiro (2016; Haushofer J, Shapiro J: The long-term effects of unconditional cash transfers: experimental evidence from Kenya, unpublished) evaluated an early version of their efforts in Kenya. In this study, villages in the target region were selected based on population and the share of households that lacked metal roofs, with households with thatch roofs selected for transfers within the villages. There was experimentation with the transfer modality (monthly vs. lump-sum; female vs. male recipients; small vs. large), but the total transfer amount was approximately PPP $\$ 1000$, made unconditionally to selected households via a mobile payment (M-PESA) account they were required to have. Approximately 9 months after the first transfer, there were no effects on labor supply or occupational choice. Households owned more livestock, owing mainly to those receiving large transfers (PPP \$1525), but their earnings or profits from agricultural and business activities were unchanged (revenues were up but so were costs). The findings indicate a relaxation of liquidity constraints, especially in the large transfer arm, but the windfall income was used primarily for consumption, assets, and upgrading to metal roofs, rather than investments causing changes in labor market outcomes. $^{13}$ 
In 2015, the Overseas Development Institute (ODI) issued a report of a high level panel on humanitarian cash transfers (ODI 2015). While the report calls for increased use of cash transfers in humanitarian assistance settings, it is largely silent on the effects of cash transfers on labor market outcomes. This is natural as increased labor market participation or change in occupational choice is not a primary goal of humanitarian assistance programs, which aim to prevent adverse outcomes for vulnerable households by ensuring adequate coverage of basic needs. Furthermore, relief operations, especially in cases of emergency, do not lend themselves to well-identified impact evaluations. However, it should be noted that refugee status is increasingly more permanent, or at least long-term, rather than temporary and, hence, assistance programs do aim to increase work opportunities and earnings for this population.

As a result, many studies of humanitarian assistance report impacts on food security and nutrition, but not on labor market outcomes. For example, randomized experiments comparing food assistance by the World Food Programme (WFP) with cash transfers (or vouchers) for Colombian refugees in Ecuador and food insecure households in Niger do not report any impacts on labor supply, earnings, or occupational choice (Hoddinott et al. 2018; Hidrobo et al. 2014). Lehmann and Masterson (Lehmann C, Masterson D: Emergency economies: the impact of cash assistance in Lebanon, unpublished) examine the effects of a winter cash assistance program targeted to Syrian refugees in Lebanon. Eligible refugees in need of assistance were selected for the program if they lived at or more than $500 \mathrm{~m}$ above sea level, which provides the identification strategy for the study. The transfers, which amounted to about \$575 during November 2013 to March 2014, reduced the share of households that reported any of their children working during the past month from $10 \%$ in the comparison group to $4 \%$ among the beneficiaries. The program also reduced adult labor supply during the past 4 weeks by $13 \%$ from 3.1 days in the comparison group to 2.7 days in the treated group. The evidence here is consistent with the standard economic model of labor supply, where beneficiaries may prefer leisure to costly (and perhaps dangerous or risky) work.

\subsection{Private transfers of cash in the form of remittances}

Remittance flows to developing countries totaled $\$ 429$ billion in 2016, exceeding the total of all international aid flows (World Bank 2017). Just as with public transfers, there is often expressed fear that these private transfers or remittances will "make people lazy" (e.g., GMA News online 2007). In response to this fear, there is a relatively large literature that attempts to measure the impact of remittances on labor outcomes. However, unlike studies of public transfers that randomly allocate transfers to some households and not others, no study has randomized private transfers to measure their response. Instead, one needs to compare the behavior of households that receive remittances to those that do not, raising concerns about the quality of much of this evidence. We therefore restrict our discussion to those studies we consider the most reliable.

One type of study considers remittances as largely unconditional cash transfers, examining what happens when a household receives a shock to the amount of remittances they receive. The clearest example is Yang (2008), who examines Filipino households with migrants abroad, where exchange rate shocks during the Asian financial crisis meant that households with migrants in some destinations suddenly experienced a large increase in remittances 
compared to households with migrants in destinations, where the local currency did not appreciate against the Philippine peso. He finds that households receiving more favorable shocks keep children in school longer and reduce child labor hours. This may be a pure income effect, or could also reflect a liquidity constraint effect that prevented households from investing as much as they wanted in schooling. The impact on total adult labor hours is positive, but not statistically significant. Adults increase the number of hours they spend in self-employment, and households are more likely to start new entrepreneurial activities. This leads to a positive, but not statistically significant, change in self-employment income, and negative, but not statistically significant, change in wage income. The impact for adults appears to be through the self-employment liquidity effect-a channel also emphasized by Woodruff and Zenteno (2007) for Mexican migrants.

A second type of study considers remittances as conditional cash transfers, where the condition to receive remittances is that the household has to send a member abroad to migrate. As a result, what can be measured is the overall impact of migration, which captures both the direct effect of higher remittances, and the indirect effects that arise from the absence of a household member. Gibson et al. (2011) use a migration lottery for Tongans wanting to migrate to New Zealand to measure these impacts on household members remaining behind in Tonga. They find no significant changes in adult labor supply or self-employment of these remaining adults. Clemens and Tiongson (2017) use a policy discontinuity that arises from Filipino migrants having to pass a language test to be able to migrate to Korea. Comparing households where this test is just passed (and so migration occurs) to those where it is just failed, they find no significant impact of migration on the hours worked or self-employment of other adults in the household.

Taken together, the more reliable studies in the literature do not support the view that remittances make recipients lazy and work less. Where good opportunities for self-employment are available, the pure remittance effect can instead alleviate credit constraints and cause more work in own businesses. But when households also lose members from migration and are in remote areas with few opportunities for business generation, this self-employment effect may not apply. Finally, the general equilibrium effect of other community members migrating to earn remittances has been to raise wages for those remaining behind (e.g., Mishra 2007; Akram et al. 2017).

\section{Specific programs that provide cash with the hope of specifically getting people to work}

The above set of public and private cash transfers were transfers made without an explicit focus on employment generation. The policy concern then has been whether people respond to those transfers by working less. In contrast, some transfer programs have a specific focus on helping poor people to find jobs, or to get better jobs. We consider three types of these programs.

\subsection{Cash transfers for search assistance and finding work}

Many governments offer job search assistance to the unemployed, with McKenzie (2017a) providing a recent review of the evidence of these programs. While the most common approaches typically just involve offering information on job vacancies and help preparing resumes, a more active approach is to give transfers to help job seekers 
cover the costs of searching for work. Examples include offering a transport subsidy in Ethiopia to cover the costs of traveling into the main city center to look for work (Franklin 2015; Abebe et al. 2016), and offering the cost of a bus ticket to the city to rural residents in Bangladesh (Bryan et al. 2014; Akram et al. 2017). These subsidies are conditional in that they could only be obtained if individuals undertook these search efforts (for example, Bryan et al. (2014) offered households cash conditional on them migrating, and Abebe et al. (2016) give the transfer to people at an office in the city center that they must travel to reach).

All three studies find the subsidies increase job search. Franklin (2015) finds the subsidies also induce a short-term reduction in temporary work, as individuals spend more time looking for more permanent jobs. The overall impact on employment in both Ethiopian studies is positive, with a 6.7 percentage point increase in employment in Franklin (2015) being significant at the 10\% level. The authors find no significant impact on earnings, but note that job seekers have moved into more formal, permanent jobs. ${ }^{14}$ The effects are stronger in Bangladesh, where the subsidies encourage migration outside of rural areas for work. Bryan et al. (2014) find household consumption increases by $30-35 \%$ during the hungry season after this subsidy is offered, with Akram et al. (2017) noting that those offered the subsidy work more and earn more. The question is then the extent to which these results stem from overcoming liquidity constraints that prevent people searching as much as they would like, or from an insurance effect that protects against the risk of not finding a job. Bryan et al. (2014) use a mixture of theory and additional experimentation to find evidence suggesting that the main channel in their case is through an insurance effect. These results suggest that conditional cash transfers for search assistance can be effective in helping individuals find work in other labor markets.

\subsection{Cash transfers for small business start-up and growth}

A second form of cash transfer program with an explicit work focus comes from grants made to potential or existing small business owners, with the goal of getting individuals to start firms, or to invest in growing their firms to earn higher profits and increase survival. ${ }^{15}$ Fafchamps et al. (2014) and McKenzie (2017b) note that an unconditional grant given to a firm owner facing no liquidity constraints would be predicted to have no effect on these business outcomes, only make the owner richer. Yet, in practice, one-time cash transfers of $\$ 100$ to $\$ 200$ given to existing firms have led to higher firm profits in Mexico (McKenzie and Woodruff 2008), Sri Lanka (de Mel et al. 2008), Ghana (Fafchamps et al. 2014), and India (Hussam et al. 2017) with returns to capital of 5\% per month or more. ${ }^{16}$ There is some evidence that conditionality matters: in Ghana the impact on firm profits is larger when transfers are given conditional on investing in the firm than when they are unconditional grants. The impacts also vary with gender, being strongly positive for males, and no average impact seen on businesses run by females. ${ }^{17}$ These grants also result in the owners working more hours in these firms, in part because the firms are more likely to survive over time due to an insurance role played by the grants (De Mel et al. 2012). Grants averaging \$382 to youth in Uganda to start-up firms, conditional on them forming groups and putting together a business plan, resulted in a $17 \%$ increase in work hours and 38\% increase in earnings (Blattman et al. 2014). 
There are a growing number of papers that compare unconditional cash grants to cash grants tied to small business start-up to understand whether unconditional cash has a similar effect. Brudevold-Newman et al. (2017) compare a micro-franchising intervention to a cash grant that gave $\$ 239$ to young women in Kenya with no encouragement to put it towards any particular use. The authors find that both the micro-franchising intervention and the cash grant lead to increased self-employment and income in the first year, but that the income effects in both arms were no longer significant after 22 months. Hicks et al. (2018) compare vocational training to cash grants (to the combination) among youth in rural Kenya. In the short run, they find that youth in the cash grant arm report an increased number of meals consumed, an improved economic situation, an increase in happiness, and an increase in self-reported health with no effects in the vocational training arm or the combined arm. In the longer term, they find that the cash impacts quickly dissipate, with again no impacts in either of the other arms.

Larger cash transfers to small businesses have occurred through business plan competitions. These competitions first screen potential entrepreneurs to find a sample with good ideas, and then award prizes to the most promising. Comparing the winners in such a competition, who received \$1000, to the runners-up, Fafchamps and Quinn (2017) find the cash transfer results in a 33 percentage-point increase in self-employment, $2.5 \mathrm{~h}$ more per week of self-employment, and higher firm profits. McKenzie (2017a, 2017b) compares winners who were randomly selected from among semi-finalists in a business plan competition in Nigeria to a control group who did not win. The winners received an average of $\$ 50,000$ each and are 7-12 percentage points more likely to be employed, 20-37 percentage points more likely to be self-employed, work 12-20 more hours in self-employment per week, and earn higher incomes. Moreover, in both studies they find these firms hire more workers, so that there is a positive employment effect for others.

The main channel that appears to be operating here is the self-employment liquidity channel. The evidence is consistent with the existence of potential and current entrepreneurs in developing countries, who have the ability to grow their businesses but just lack capital to do so. Transfers, which alleviate this credit constraint, can then increase employment and earnings for them. Making the transfers conditional on investment in the business appears to help some individuals overcome self-control problems, enhancing this impact relative to unconditional cash (Fafchamps et al. 2014).

\subsection{Combination interventions of transfers and training}

We conclude our review with a short discussion of programs that provide very poor households not only with one-off asset transfers, but also with stipends (consumption support) and intensive skills training for a fixed, but relatively long, period. We consider two studies of BRAC's “Targeting the Ultra-Poor" or TUP program (Banerjee et al. 2015; Bandiera et al. 2017) and a study of cash transfers, skills training, and supervision (Blattman et al. 2016). While these studies do not attempt to separate the effects of cash transfers from training, they are useful because (a) they are designed to affect labor market outcomes through occupational change, and (b) Bandiera et al. (2017) is one of the few studies that touches on GE effects.

TUP is a program that is designed and implemented by BRAC in rural Bangladesh to reach ultra-poor women who are not recipients of other forms of assistance, such as 
microfinance or government safety nets (Bandiera et al., 2017). Households with able-bodied women, who were categorized as ultra-poor after a participatory wealth-ranking exercise in each village, were offered a menu of productive assets (with menus that included at least one cow being overwhelmingly preferred) along with a support and training package that allows households to learn how to rear livestock and for them to smooth consumption. Bandiera et al. (2017) find that, 4 years after the initial transfer (or 2 years after the cessation of all support), ultra-poor women in treatment villages spend more time rearing livestock and less time in casual wage (agricultural) labor and maid services. The program has a net effect on hours and days worked of 17 and $22 \%$, respectively, indicating idle work capacity that the program could direct towards productive activities by releasing a combination of credit, insurance, and human capital constraints. ${ }^{18}$ As interventions addressing each of these constraints are bundled into the program, the exact mechanisms at play are uncertain. As the market share of new entrants was small, the program had no effect on the labor supply or earnings among richer ineligible households with livestock-rearing businesses. However, agricultural and maid wages increased by 9 and 11\%, respectively, as these activities were primarily undertaken by the ultra-poor at baseline. Hence, the program had some general equilibrium effect on wages in these rural village economies. ${ }^{19}$

The TUP model was adapted to suit different contexts while staying true to the same overall principles of design and evaluated in six other countries: Ethiopia, Ghana, Honduras, India, Pakistan, and Peru (Banerjee et al. 2015). The findings, 3 years after the asset transfers or 1 year after cessation of all support, are like Bandiera et al. (2017) but weaker: adult labor supply increases modestly by about 0.05 standard deviations (or about $6 \%$ over control households), much of which comes from time spent working on livestock. Livestock revenue, agricultural income, and microenterprise income are all significantly higher on average in these six countries, but the income gains are modest (less than $0.1 \mathrm{SD}$ ) and heterogeneous across countries. Changes in time use is statistically significant in only three of the six countries. The authors, comparing their findings to Bandiera et al. (2017), note the striking similarities in effect sizes between neighboring India and Bangladesh. In both studies, analyses of quantile treatment effects indicate that the effects are at least an order of magnitude larger at the top of the asset/consumption distribution than at the bottom.

Women's Income Generation Support program (WINGS) in Northern Uganda has parallels to the TUP model in that it bundled cash transfers with business skills training and planning, along with ongoing supervision to implement the plan (Blattman et al. 2016). ${ }^{20}$ The WINGS program differs from TUP programs in several ways, perhaps the most important of which is that it targets a non-random sample of ultra-poor women in the villages the implementing NGO operated. ${ }^{21}$ WINGS also had fewer bundled components than TUP, gave cash instead of livestock, focused on petty trade rather than animal husbandry, and took place in a post-war setting in Northern Uganda. The evaluation also had a shorter duration (16 months after the lump-sum transfer of cash) than studies of TUP.

At the 16-month follow-up, participants in the treatment villages were twice as likely to own non-farm businesses, worked 9 more hours per week, and earned about $\$ 0.40$ (PPP \$1) more than those in the control areas. The authors argue that the consumption effects are almost identical to the TUP effects discussed above with WINGS being a lower-cost program than TUP programs that have larger transfers and more intense 
training and support. Again, the exact channels of impact are unclear in this bundled experiment, but further experimentation with the intensity of support when the control group was treated after the 16-month follow-up found higher business survival among those with more supervision, but was equivocal on earnings and consumption.

In summary, while evaluations of these programs do point to the possibility that they lead to increased employment, earnings, consumption, and wealth among the participants by relaxing the liquidity constraint for self-employment, it is not possible to isolate this channel from increases in human capital or from other forms of support provided under these programs. However, the Bandiera et al. (2017) does point to GE effects on wages in the low-skilled sector, although again this effect may also be a result of a bundle of interventions rather than just cash (or in kind) grants that caused substantive occupational change among program beneficiaries.

\section{Conclusions}

Table 1 summarizes our reading of the overall evidence in the literature for the typical impacts of different types of cash transfer programs. The simple "Econ 101" model in which the income effect of a cash transfer results in recipients reducing work and increasing leisure is very seldom what we see happening in reality. The closest approximation to this model appears to come in the labor of the elderly when they receive government pensions. Yet this is hardly the group for whom more leisure is viewed as being a social bad, and there are few headlines excoriating lazy pensioners. In contrast, prime age adults tend to see very little change in either the amount they work, or the amount they earn when receiving unconditional or conditional cash transfers, or charitable grants. Likewise,

Table 1 Summary of adult labor impacts of different types of cash transfers

\begin{tabular}{|c|c|}
\hline Transfer type & Typical impact on labor outcomes \\
\hline $\begin{array}{l}\text { Government cash transfers: } \\
\text { CCTs }\end{array}$ & $\begin{array}{l}\text { No effect on total work or leisure; Small effects on self-employment and } \\
\text { entrepreneurship in the short run; mixed evidence on adult labor outcomes } \\
\text { for young adults who were children in beneficiary households. }\end{array}$ \\
\hline $\begin{array}{l}\text { Government cash transfers: } \\
\text { UCTs }\end{array}$ & $\begin{array}{l}\text { Cash transfers to working age adults have resulted in a change in the type } \\
\text { of work, with more self-employment and own agriculture. Pensions decrease } \\
\text { amount worked by the elderly, and have mixed results on other adults living } \\
\text { with them, with some doing more migration and self-employment, and others } \\
\text { enjoying more leisure. }\end{array}$ \\
\hline $\begin{array}{l}\text { Charitable giving and } \\
\text { humanitarian transfers }\end{array}$ & $\begin{array}{l}\text { No short-term effect on total work or work income when given in non- } \\
\text { disaster/non-refugee situation, reduced work slightly among refugees. } \\
\text { Few studies consider labor outcomes or look long-term. }\end{array}$ \\
\hline Remittance transfers & $\begin{array}{l}\text { Limited impact on labor of adults in receiving household; some evidence of a } \\
\text { positive impact on self-employment in some cases, but more common is no } \\
\text { impact. }\end{array}$ \\
\hline $\begin{array}{l}\text { Cash transfers for search } \\
\text { assistance and finding work }\end{array}$ & $\begin{array}{l}\text { Increases job search, resulting in a temporary reduction in work, but then in a } \\
\text { higher chance of being employed in higher paying work. Impacts strongest } \\
\text { when subsidy is for finding work in a different labor market, including fostering } \\
\text { internal migration. }\end{array}$ \\
\hline $\begin{array}{l}\text { Cash transfers for business } \\
\text { start-up and growth }\end{array}$ & $\begin{array}{l}\text { Small grants have typically increased business start-up and survival, and } \\
\text { increased business earnings. Impacts on work, and total labor income } \\
\text { tend to be smaller, but still positive. Larger grants targeted at higher-growth } \\
\text { entrepreneurs also have created jobs for others. }\end{array}$ \\
\hline $\begin{array}{l}\text { Combination transfers of cash, } \\
\text { training, and assets }\end{array}$ & $\begin{array}{l}\text { Ultra-poor programs changed type of work towards more livestock-rearing, } \\
\text { increased total work hours and work income. Unclear how much of this is } \\
\text { due to cash versus other program components. General equilibrium effect } \\
\text { increases wages for other occupations in the village. }\end{array}$ \\
\hline
\end{tabular}


the more credible studies have not found evidence of adults in migrant households reducing labor when they receive remittances, and in some cases, they work more through increased household enterprises. The "Econ 101" model is even more likely to give the incorrect prediction when it comes to cash transfers made for job search and for starting businesses. Transfers that enable people to find jobs in different places, and to start up new businesses, have resulted in more labor and higher income for the recipients.

In Table 2, we summarize the theoretical channels through which cash transfers could affect adult labor market outcomes, and our reading of which seem most apparent from the existing literature. The income effect underlying the labor-leisure trade-off appears

Table 2 Summary of different channels through which cash transfers affect labor outcomes

\begin{tabular}{ll}
\hline Channel & Direction of impact and evidence \\
\hline Income effect/labor-leisure trade-off & Reduces amount of work at both extensive and intensive margins, \\
& with no change in income per hour worked. Most apparent when \\
& transfers are large or prolonged, and when recipients face no other \\
& constraints: e.g., lottery winners, pensions.
\end{tabular}

Health productivity effect

Self-employment liquidity effect

Human capital accumulation effect

Insurance effect

Investment in labor search effect

Conditionality effect from conditioning on work or not working

Conditionality effect from conditioning on time-consuming activities

Human capital/scarring effect

General equilibrium effects
Increases amount of work, and income earned per hour worked. This channel is unlikely to apply in most settings, but may have an impact for transfers to the very poorest.

Increases amount of self-employment work at both extensive and intensive margins, and income earned from self-employment. Typically a smaller, but positive, impact on all work. Clearest for programs that target entrepreneurs, particularly men, but also apparent in remittance transfers and UCTs.

Increases schooling attainment for youth in recipient households that can result in long-term increases in income from higher human capital when they become adults. Impact on amount worked is minimal. Evidence from existing CCTs mixed between zero and positive impacts.

Changes the type of work people do, towards riskier activities that increase expected income, like self-employment, migration, or different crops, with less impact on amount worked. Applies most when transfers are reliable and repeated: e.g., some CCTs

Reduces likelihood of working in very short term as workers search for better matches. Increases job quality, and income per hour worked in medium-term, with little impact on amount work. Applies most for transfers conditioned on job search, like transport subsidies.

Increases amount of work if grants given conditional on operating a business or other work activity. Some evidence from grants to microenterprises suggest this channel operates. Decreases work or income if grant eligibility depends on means-testing, or on not working. More of an issue for upper middle income and rich countries, with little evidence of this channel for most low- and middle-income country cash transfers.

Reduces work if individuals must spend time on activities in order to receive grant, but little evidence of this channel operating. Can increase amount worked, particularly by women, if condition is for children to be in school. Most apparent for CCTs.

Counteracts labor/leisure tendency to reduce work if transfers are known to be temporary. Appears plausible, but no evidence for this channel in existing literature.

Transfers can increase work and work income for non-beneficiaries if self-employment opportunities increase and transfer recipients move away from wage labor; may reinforce labor/leisure trade-off if value of leisure rises when others also increase leisure. Limited evidence, although ultra-poor program in Bangladesh and emigration studies find increased wages for others in village. 
most apparent when transfers are large and/or prolonged (as with lottery winnings and pensions), and appears to be much weaker for one-time transfers. The most important alternative channel appears to be a liquidity effect, whereby cash transfers allow households to make investments in agricultural and non-farm businesses that they would otherwise not be able to do, increasing the returns to work and causing individuals to work more. A second and related channel in some cases is through providing insurance that can spur investment in new risky activities like self-employment or migration. There is more limited evidence for some of the other channels operating: conditions of the transfer can cause more to be spent on business activities, and cash transfers that increase education can result in better labor market outcomes for these adolescents when they become adults. In contrast, there are several channels that might operate, but for which the existing literature does not provide evidence. These include the human capital depreciation or scarring effect, work impacts of grant eligibility conditions, and health productivity effects.

The existing literature does have some additional limitations. Much of the literature just reports the overall impact of a cash transfer on a given labor outcome, without unpacking the channels through which this impact occurs. In addition, studies often focus on different types of work outcomes. Some just measure formal labor, or self-employment and business profits; many do not examine the intensive margin of work (hours); and so consistent measurement on the likelihood of working, amount worked, and total work income is not always available. Additional attention to common measurement of outcomes and further discussion of mechanisms would improve the literature base, thus making a more formal meta-analysis of these programs a possibility in the future.

As cash transfers continue to proliferate in LMICs, the presumption that they will undermine work effort and have less impact than anticipated through a resulting reduction in labor income seems largely unfounded. But the impacts are likely to be different when transfers are dependable and permanent rather than temporary and/or surprises, when the eligibility criteria are known in advance to recipients compared to programs being unannounced, and when targeted at different types of people. There is thus an active role for future research to attempt to better measure and unpack the different channels we describe in this paper, and to better understand the heterogeneity of impacts as program features and program beneficiaries change.

\section{Endnotes}

${ }^{1}$ Campbell Collaboration states that a systematic review must have (a) clear inclusion/ exclusion criteria, (b) an explicit search strategy, (c) systematic coding and analysis of included studies, and (s) meta-analysis (where possible). Our review does not satisfy any of these criteria, but comes closest to having a clear inclusion criterion: the intervention studied must include a cash transfer, have a study deemed well-identified, and the study should report impacts on at least one labor market outcome. We are more interested in exploring the mechanisms behind the effects of interventions and provide a little more nuance on each study than large systematic reviews, which make the narrative review a more suitable review methodology for us.

${ }^{2}$ Kraay and McKenzie (2014) summarize the evidence for such a mechanism causing poverty traps, which they find to be weak, but note that there may still be a productivity effect even with no trap. More generally, we can also include under this explanation 
any mental depletion impacts of poverty that make individuals less productive, as in Shah et al. (2012).

${ }^{3}$ There is also a literature on the impact of cash transfers on child labor that is beyond the scope of this review. See de Hoop and Rosati (2014) for a review of this literature.

${ }^{4}$ These programs include Honduras' PRAF II, Morocco's Tayssir, Mexico's PROGRESA and PAL, Philippines' PPPP, Indonesia's PKH, and Nicaragua's RPS. Two were not entirely conditional. Mexico's PAL program, where benefits were not conditioned on behaviors and Morocco's Tayssir program, which had two treatment arms consisting of a CCT and a "labeled cash transfer".

${ }^{5}$ There is a related parallel literature, mostly from high-income countries, on the effects of universal cash transfer programs or universal basic income. Examining lottery winners in Sweden and Netherlands, beneficiaries of negative income tax experiments in Canada, and recipients of fund dividend programs in the USA, studies consistently find small reductions in earnings and hours worked (Cesarini et al. 2017; Marinescu 2018; Picchio M, Suetens S, van Ours J: Labour supply effects of winning a lottery, forthcoming). Using a large and universal cash transfer program in Iran that was implemented to offset large increases in prices of energy and bread (because of removal of large subsidies), Salehi-Isfahani and Mostafavi-Dehzooei (2017) find no effects (of the combined reform of cash transfers and price increases) on weekly hours worked.

${ }^{6}$ Interestingly, in both countries, children's engagement in economic activity (including agricultural work for the household, herding livestock, and household chores) and their exposure to hazardous work increase among beneficiary households, without negative effects on school attendance, presumably due to the increased own-agricultural and non-farm enterprise activity. This finding implies that leisure time must decrease for children under these UCT programs and contrasts with findings from CCT programs that consistently find decreases in child labor and increases in school attendance.

${ }^{7}$ Ralston et al. (2017) conduct a meta-analysis of 27 safety net programs in Africa (including the Malawi and Zambia programs discussed here), of which 20 reported some outcomes on productive assets. They find that only six report significant earnings or productivity increases, calling "...into question the ability for all safety net programs to obtain the desired productive impacts they may hope for." They find no significant effects on employment or business ownership, but positive effects on earnings - the latter two showing a high degree of heterogeneity in impacts.

${ }^{8}$ The finding on female pensioners is consistent with Ambler (2016), who finds that women experience much larger gains in income than men after becoming eligible for pensions in South Africa, because eligibility does not increase incomes for males, who withdraw from the labor force.

${ }^{9}$ Kaushal (2014) also finds declines in employment rates in India in response to the expansion of the pension system to all poor elderly, but the declines are small (3-6 pp. or $4-8 \%$ ), perhaps because pension amounts are not high enough to cause large-scale retirement.

${ }^{10}$ Kugler and Rojas (2018) claim large effects on employment, hours worked, and earnings for those 7-16 years of age prior to the introduction of PROGRESA, but the paper suffers from very high levels of attrition after 2003. Employing a difference-in-difference estimation strategy using the 2010 census, Parker and Vogl (2018) find that females fully 
exposed to PROGRESA (i.e., when they were between the ages of 7-11 when the program was rolled out in their communities) were more likely to be working for pay and had higher monthly labor incomes. However, they do not find the same effects for males.

${ }^{11}$ Evaluating a similar scholarship program targeted to students entering Grade 4 9 years after the introduction of the program, (Barrera-Osorio F, de Barros A, Filmer D: Long-term impacts of alternative approaches to increase schooling: evidence from an experimental scholarship program in Cambodia, unpublished) find a small and marginally significant effect on the probability of working (3.4 pp. over a base of $92.5 \%$ in the control group). The effect was only among the group that received merit-based scholarships rather than need-based ones.

${ }^{12}$ Note that this is not a government program, but a pilot program designed by the researchers and run by an NGO.

${ }^{13} \mathrm{~A}$ longer-term evaluation of the same program finds an increased level of assets among transfer recipients, but no other impacts (Haushofer J, Shapiro J: The Long-Term Impact of Unconditional Cash Transfers: Experimental Evidence from Kenya, unpublished).

${ }^{14}$ McKenzie (2017a) provides a critical review of such studies, noting that employment outcomes tend to be measured over relatively short time horizons, so that it is unclear whether the impacts last, and noting that more formal jobs need not necessarily be better jobs.

${ }^{15}$ We consider here only studies of programs which just provide transfers to businesses, and not those of studies which measure the combined effect of cash transfers and training (e.g., De Mel et al. 2014 in Sri Lanka; Blattman et al. 2016 in Uganda), which we discuss in the next sub-section.

${ }^{16}$ Small grants had positive, but not statistically significant, impacts in studies in Uganda (Fiala 2014) and Tanzania (Berge et al. 2014).

${ }^{17}$ Bernhardt et al. (2017) offer an explanation for this by showing that grants to female owners can lead to increased business income for other household members.

${ }^{18}$ Additional work translated into higher consumption, savings, productive assets, and access to land for these households.

${ }^{19}$ (Muralidharan K, Niehaus P, Sukhantankar S: General Equilibrium Effects of (Improving) Public Employment Programs: Experimental Evidence from India, unpublished) report similar GE effects on low-skilled wages from improvements in the performance of the National Rural Employment Guarantee Scheme in Andhra Pradesh, India.

${ }^{20}$ Blattman and Dercon (2016) report findings from a similar entrepreneurship program that provided 5 days of business training followed by a $\$ 300$ unconditional grant to industrial job applicants in Ethiopia. They find no effects on employment and occupational choice, but evidence of increased income.

${ }^{21}$ Association of Volunteers in International Service (AVSI) held meetings to describe the program in each village and asked communities to nominate marginalized villagers, requiring three quarters of them to be young women. AVSI then interviewed all nominees and selected a subset for inclusion in the program. 
Funding

The authors acknowledge support from the IZA/DFID Growth and Labour Markets in Low-Income Countries Programme.

\section{Competing interests}

The IZA Journal of Development and Migration is committed to the IZA Guiding Principles of Research Integrity. The authors declare that they have observed these principles.

\section{Publisher's Note}

Springer Nature remains neutral with regard to jurisdictional claims in published maps and institutional affiliations.

\section{Author details}

${ }^{1}$ Department of Global Health at the Milken Institute School of Public Health, George Washington University, Washington, DC, USA. ${ }^{2}$ Development Research Group, The World Bank, Washington, DC, USA.

Received: 11 April 2018 Accepted: 28 June 2018

Published online: 12 December 2018

\section{References}

Abebe G, Caria S, Fafchamps M, Falco P, Franklin S, Quinn S. (2016). "Curse of Anonymity or Tyranny of Distance? The Impacts of Job-Search Support in Urban Ethiopia", NBER working paper no. 22409.

Akram AA, Chowdhury S, Mushfiq Mobarak A. Effects of emigration on rural labor markets. Yale: Mimeo; 2017.

Ambler K. Bargaining with grandma. The impact of the South African pension on household decision-making. J Hum Resour. 2016;51(4):900-32.

Araujo MC, Bosch M, Schady N. Can cash transfers help households escape an inter-generational poverty trap? NBER Working Paper 22670: National Bureau of Economic Research; 2016.

Ardington C, Case A, Hosegood V. Labor supply responses to large social transfers: longitudinal evidence from South Africa. Am Econ J. 2009;1 (1):22-48.

Baird S, Ferreira F, Özler B, Woolcock M. Conditional, Unconditional and Everything in Between: A Systematic Review of the Effects of Cash Transfer Programs on Schooling Outcomes. J Dev Eff. 2014;6(1):1-43.

Bandiera O, Burgess R, Das N, Gulesci S, Rasul I, Sulaiman M. Labor Markets and Poverty in Village Economies. Q J Econ. 2017;132(2):811-70. https://doi.org/10.1093/qje/qjx003.

Banerjee A, Duflo E, Goldberg N, Karlan D, Osei R, Parienté W, Shapiro J, Thuysbaert B, Udry C. A multifaceted program causes lasting progress for the very poor: Evidence from six countries. Science. 2015;348(6236):1260799.

Banerjee AV, Hanna R, Kreindler GE, Olken BA. Debunking the stereotype of the lazy welfare recipient: evidence from cash transfer programs. World Bank Res Obs. 2017;32(2):155-84.

Barham T, Macours K, Maluccio JA Are Conditional Cash Transfers Fulfilling Their Promise? Schooling, Learning, and Earnings after 10 Years. CEPR Discussion Paper No. DP11937. 2017. Available at SSRN: https://ssin.com/abstract= 2941523.

Becker G. A theory of the allocation of time. Econ J. 1965;75(299):493-517.

Behrman JR, Parker SW, Todd PE. Do conditional cash transfers for schooling generate lasting benefits? J Hum Resour. 2011:46(1):93-122

Berge LIO, Bjorvatn K, Tungodden B. Human and financial capital for microenterprise development: evidence from a field and lab experiment. Manag Sci. 2014;61(4):707-22.

Bernhardt A, Field E, Pande R, Rigol N. "Household matters: revisiting the returns to capital among female microentrepreneurs", Mimeo. MIT. 2017

Bertrand M, Mullainathan S, Miller D. Labor supply responses to large social transfers: longitudinal evidence from South Africa. World Bank Econ Rev. 2003;17(1):27-50

Bianchi M, Bobba M. Liquidity, risk, and occupational choices. Rev Econ Stud. 2013;80:491-511.

Blattman C, Dercon S. (2016). "Occupational Choice in Early Industrializing Societies: Experimental Evidence on the Income and Health Effects of Industrial and Entrepreneurial Work" NBER Working Paper No. 22683.

Blattman C, Fiala N, Martinez S. Generating skilled self-employment in developing countries: experimental evidence from Uganda. Q J Econ. 2014;129(2):697-752.

Blattman C, Green E, Jamison J, Lehmann C, Annan J. The returns to microenterprise support among the ultrapoor: a field experiment in postwar Uganda. Am Econ J. 2016;8(2):35-64.

Brudevold-Newman, Andrew, Maddalena Honorati, Pamela Jakiela and Owen Ozier (2017) "A firm of one's own: Experimental evidence on credit constraints and occupational choice", World Bank Policy Research Working Paper no. 7977.

Bryan G, Chowdhury S, Mushfiq Mobarak A. Underinvestment in a profitable technology: the case of seasonal migration in Bangladesh. Econometrica. 2014;82(5):1671-748.

Cesarini D, Lindqvist E, Notowidigdo MJ, Östling R. The Effect of Wealth on Individual and Household Labor Supply: Evidence from Swedish Lotteries. Am Econ Rev. 2017;107(12):3917-46.

Clemens M, Tiongson E. Split decisions: household finance when a policy discontinuity allocates overseas work. Rev Econ Stat. 2017;99(3):531-43.

Dasgupta P, Ray D. Inequality as a determinant of malnutrition and unemployment: theory. Econ J. 1986;96(384): 1011-34.

de Hoop J, Rosati FC. Cash transfers and child labor. World Bank Res Obs. 2014;29(2):202-34.

De Mel S, McKenzie D, Woodruff C. Returns to capital: results from a randomized experiment. Q J Econ. 2008;123(4): 1329-72. 
De Mel S, McKenzie D, Woodruff C. One-time transfers of cash or capital have long-lasting effects on microenterprises in Sri Lanka. Science. 2012;335:962-6.

De Mel S, McKenzie D, Woodruff C. Business training and female enterprise start-up, growth, and dynamics: experimental evidence from Sri Lanka. J Dev Econ. 2014;106:199-210.

Evans DK, Popova A. What really works to improve learning in developing countries? An analysis of divergent findings in systematic reviews. World Bank Res Obs. 2016;31:242-70.

Fafchamps M, McKenzie D, Quinn S, Woodruff C. Microenterprise growth and the flypaper effect: evidence from a randomized experiment in Ghana. J Dev Econ. 2014:106:211-26.

Fafchamps M, Quinn S. Aspire. J Dev Stud. 2017;53(10):1615-33.

Fiala N. "Stimulating microenterprise growth: results from a loan, grants, and training experiment in Uganda", Mimeo. University of Connecticut. 2014

Filmer D, Schady N. The medium-term effects of scholarships in a low-income country. J Hum Resour. 2014;49(3):663-94.

Franklin S. (2015). "Location, search costs and youth unemployment: a randomized trial of transport subsidies in Ethiopia." Centre for the study of African economies working paper WPS/2015-11.

Gentilini U, Honorati M, Yemtsov R. The state of social safety nets 2014. Washington, DC: World Bank Group; 2014.

Gertler PJ, Martinez SW, Rubio-Codina M. Investing cash transfers to raise long-term living standards. Am Econ J. 2012; 4(1):164-92.

Gibson J, McKenzie D, Stillman S. The impacts of international migration on remaining household members: omnibus results from a migration lottery program. Rev Econ Stat. 2011;93(4):1297-318.

GMA News online (2007) "Money from overseas makes OFW kids 'lazy", September 28, http://www.gmanetwork.com/ news/news/content/62394/money-from-overseas-makes-ofw-kids-lazy/story/. Accessed 10 Oct 2017.

Ham A, Michelsen HC. Does the form of delivering incentives in conditional cash transfers matter over a decade later? J Dev Econ. 2018; https://doi.org/10.1016/j.jdeveco.2018.05.007.

Hamoudi A, Thomas D. Endogenous coresidence and program incidence: South Africa's old age pension. J Dev Econ. 2014;109:30-7.

Handa S, Natali L, Seidenfeld D, Tembo G, Davis B, on behalf of the Zambia Cash Transfer Evaluation Study Team. Can unconditional cash transfers raise long-term living standards? Evidence from Zambia. J Dev Econ. 2018; https://doi. org/10.1016/j.jdeveco.2018.01.008.

Haushofer J, Shapiro J. The short-term effects of unconditional cash transfers to the poor: experimental evidence from Kenya. Q J Econ. 2016;131(4):1973-2042.

Hicks JH, Kremer M, Mbiti I, Miguel E. "Addressing youth unemployment through training and grants: experimental evidence from Kenya." ASSA 2018 Presentation. 2018.

Hidrobo M, Hoddinott J, Peterman A, Margolies A, Moreira V. Cash, food, or vouchers? Evidence from a randomized experiment in northern Ecuador. J Dev Econ. 2014;107:144-56.

Hoddinott J, Sandström S, Upton J. The Impact of Cash and Food Transfers: Evidence from a Randomized Intervention in Niger. Am J Agric Econ. 2018;100(4):1032-49. https://doi.org/10.1093/ajae/aay019.

Hussam R, Rigol N, Roth B. Targeting high ability entrepreneurs using community information: mechanism design in the field: Mimeo. MIT; 2017.

Kaushal N. How public pension affects elderly labor supply and well-being: evidence from India. World Dev. 2014;56:214-25.

Keynes JM. Economic possibilities for our grandchildren. In: Essays in Persuasion. New York: W.W. Norton and Co; 1930. p. 358-73.

Kraay A, McKenzie D. Do poverty traps exist? Assessing the evidence. J Econ Perspect. 2014;28(3):127-48.

Kugler, Adriana D., and Ingrid Rojas (2018). "Do CCTs improve employment and earnings in the very long-term? Evidence from Mexico," NBER Working Paper No. 24248.

Lam D, Leibbrandt M, Ranchhod V. Labor force withdrawal of the elderly in South Africa. In: Cohen B, Menken J, editors. Aging in sub-Saharan Africa: recommendations for furthering research. Washington, DC: The National Academies Press; 2006.

Manley J, Gitter S, Slavchevska V. How Effective are Cash Transfers at Improving Nutritional Status?. World Dev. 2013;48:133-55.

Marinescu, loana (2018). "No strings attached: the behavioral effects of U.S. unconditional cash transfer programs." NBER Working Paper 24337.

McKenzie D. How effective are active labor market policies in developing countries? A critical review of recent evidence. World Bank Res Obs. 2017a;32(2):127-54.

McKenzie D. Identifying and spurring high-growth entrepreneurship: experimental evidence from a business plan competition. Am Econ Rev. 2017b;107(8):2278-307.

McKenzie D, Woodruff C. Experimental evidence on returns to capital and access to finance in Mexico. World Bank Econ Rev. 2008;22(3):457-82.

Mishra P. Emigration and wages in source countries: evidence from Mexico. J Dev Econ. 2007;82:180-99.

Overseas Development Institute (2015): "Doing cash differently: how cash transfers can transform humanitarian aid," Report accessed on 2/22/2018

Parker SW, Skoufias E. Final Report: The Impact of PROGRESA on Work, Leisure, and Time Allocation. Washington, DC: International Food Policy Research Institute; 2000.

Parker SW, Todd PE. Conditional cash transfers: the case of Progresa/Oportunidades. J Econ Lit. 2017;55(3):866-915.

Parker, Susan W., and Tom Vogl (2018). "Do conditional cash transfers improve economic outcomes in the next generation? Evidence from Mexico." NBER Working Paper 24303.

Posel D, Fairburn JA, Lund F. Labour migration and households: a reconsideration of the effects of the social pension on labour supply in South Africa. Econ Model. 2006;23:836-53.

Prifti E, Estruch E, Daidone S, Davis B, van Ufford P, Michelo S, Handa S, Seidenfeld D, Gelson T. Learning about labour impacts of cash transfers in Zambia. J Afr Econ. 2017;26(4):433-42.

Ralston L, Andrews C, Hsiao A. (2017). "The impacts of safety nets in Africa: what are we learning?" World Bank Policy Research Working Paper Series No. 8255. 
Ranchhod V. The effect of the South African old age pension on labour supply of the elderly. S Afr J Econ. 2006;74(4):725-44.

Rubio-Codina M. Intra-household Time Allocation in Rural Mexico: Evidence from a Randomized Experiment. Res Labor Econ. 2010;31:219-57.

Salehi-Isfahani D, Mohammad H. Mostafavi-Dehzooei (2017). "Cash transfers and labor supply: evidence from a largescale program in Iran," Economic Research Forum Working Paper Series No. 1090.

Shah A, Mullainathan S, Shafir E. Some consequences of having too little. Science. 2012;338(6107):682-5.

Woodruff C, Zenteno R. Migration networks and microenterprises in Mexico. J Dev Econ. 2007;82:509-28.

World Bank (2017) "Trends in Migration and Remittances 2017". http://www.worldbank.org/en/news/infographic/2017/ 04/21/trends-in-migration-and-remittances-2017. Accessed 10 Oct 2017.

Yang D. International migration, remittances, and household investment: evidence from Philippine migrants' exchange rate shocks. Econ J. 2008;118:591-630.

Submit your manuscript to a SpringerOpen ${ }^{\circ}$ journal and benefit from:

- Convenient online submission

- Rigorous peer review

- Open access: articles freely available online

- High visibility within the field

- Retaining the copyright to your article

Submit your next manuscript at $\gg$ springeropen.com 